\title{
STUDI DISKRIPTIF TENTANG MOBILISASI DINI TERHADAP PENGELUARAN LOCHEA PADA IBU NIFAS HARI KE-4
}

\author{
Mariyatul Qiftiyah', Karimatul Ulya ${ }^{2}$ \\ ${ }^{1}$ Prodi D3 Kebidanan STIKES Nahdlatul Ulama Tuban \\ ${ }^{2}$ Prodi D3 Kebidanan STIKES Nahdlatul Ulama Tuban
}

\begin{abstract}
ABSTRAK
Masa nifas (puerperium) adalah masa setelah plasenta lahir dan berakhir ketika alat-alat kandungan kembali seperti keadaan sebelum hamil. Pada masa nifas terjadi perubahan fisiologi salah satunya adalah involusi uteri. Dalam proses involusi uteri terjadi pengeluaran lochea yang dipengaruhi oleh beberapa faktor yaitu mobilisasi dini. Tujuan umum dalam penelitian ini adalah untuk mengetahui studi diskriptif tentang mobilisasi dini terhadap pengeluaran lochea pada ibu nifas hari ke-4 di BPM Asri dan Polindes Permata Bunda Tuban.

Penelitian ini menggunakan metode deskriptif dengan populasi seluruh ibu nifas yang usia lebih dari 3 hari pada bulan Maret- Mei tahun 2018 diBPM Asri dan Polindes Permata Bunda Tuban. Teknik sampling menggunakan purposive sampling yaitu sebesar 32 responden. Variabel yang diteliti adalah mobilisasi dini dan pengeluaran lochea.

Hasil penelitian yang di laksanakan di BPM Asri dan Polindes Permata Bunda pada bulan Maret- mei dari 32 responden,sebagian besar 21 (65,62\%) responden melakukan mobilisasi dini dengan cepat, dan sebagian besar 18 $(56,25 \%)$ responden dengan pengeluaran lochea sesuai.

Dapat disimpulkan bahwa hampir sebagian besar ibu nifas melakukan mobilisasi dini dengan cepat dan dengan pengeluaran lochea sesuai. Sebaiknya dilakukan peningkatan mutu pelayanan disetiap instansi pelayanan kesehatan dengan selalu memberikan informasi tentang perubahan psikologis, fisiologis dan pengeluaran lochea pada ibu nifas.
\end{abstract}

\section{Kata Kunci : Mobilisasi Dini, Lochea}

\section{ABSTRACT}

Puerperium is the period after the placenta is born and ends when the gynecological devices return like pre pregnancy. In the puerperium physiological changes, one of them is uterine involution. In the process of uterine involution occurs expenditure lochea which is influenced by several factors namely early mobilization. The general purpose of this research is to know the descriptive study about early mobilization of lochea expenditure on the 4th day of the puerperal mother at BPM Asri and Polindes Permata Bunda Tuban.

This study used descriptive method with population of all postpartum mothers aged more than 3 days in march - May 2018 at BPM Asri and Polindes 
Permata Bunda Tuban. Sampling technique using purposive sampling that is equal to 32 respondents. The variables studied were early mobilization and lochea expenditure.

The results of the survey conducted at BPM Asri and Polindes Permata Bunda in march-may of 32 respondents got 18 (56.25\%) people with normal lochea corresponding, and 21 (65.62\%) postpartum early mobilization quickly. Of the majority of postpartum women perform early mobilization and a normal lochea corresponding.

From the results of this study can be concluded that almost most postpartum early mobilization quickly and lochea dispensing accordingly. but it should be noted also in postpartum women who do not do early mobilization with abnormal lochea expenditure, so that mothers pay more attention from the benefits of early mobilization and so prosese spending of lochea can run according to the time.

\section{Keywords: Early Mobilization, Lochea}

\section{PENDAHULUAN}

Masa nifas atau puerperium dimulai sejak 1 jam setelah lahirnya plasenta sampai dengan 6 minggu (42 hari) setelah itu. Pada masa nifas ini terjadi perubahan-prubahan fisiologi seperti perubahan fisik, involusi uteri, dan pengeluaran lochea, laktasi, perubahan psikologi dan perubahan sisitem tubuh lainnya (Prawirohardjo, 2010).

Dinas Kesehatan Provinsi Jawa Timur menyatakan bahwa pada tahun 2014 Angka Kematian Ibu mengalami peningkatan yaitu sebesar 126,55 per 100.000 kelahiran hidup, sedangkan pada tahun 2013 sebesar 118,62 per 100.000 kelahiran hidup. Sebesar 57,95\% kematian maternal terjadi pada waktu nifas, pada waktu hamil sebesar $27,00 \%$ dan pada waktu persalinan sebesar $15,05 \%$. Penyebab kematian ibu menurut Dinas Kesehatan Provinsi Jawa Timur pada tahun 2014 diantaranya karena pendarahan sebesar 22,93\%, hipertensi 26,44\%, infeksi 3,66\%, gangguan sistem peredaran darah $4,64 \%$, dan lain-lain 42,33\%.

\begin{abstract}
Pada masa nifas terjadi pengeluaran cairan sekret yang berasal dari kavum uteri dan vagina yang disebut sebagai lochea. Lochea merupakan ekskresi cairan rahim selama masa nifas dan mempunyai reaksi bassa/alkalis yang dapat membuat organisme berkembang lebih cepat dari kondisi asam yang ada pada vagina normal. Lochea mempunyai bau yang amis (anyir) meskipun tidak terlalu menyengat dan volumenya berbeda-beda pada setiap wanita. Lochea mengalami perubahan karena proses involusi. Pengeluaran lochea dapat dibagi berdasarkan waktu dan warnanya yaitu. Lochea terbagi menjadi tiga jenis yaitu : Lochea rubra (cruenta) berwarna merah karena berisi darah segar dan sisa-sisa selaput ketuban, set-set desidua, verniks caseosa, lanugo, dan mekonium selama 2 hari pascapersalinan, Lochea sanguilenta berwarna merah kuning berisi darah dan lendir yang keluar pada hari ke-3 sampai ke-7 pascapersalinan, Lochea serosa dimulai dengan versi yang lebih pucat dari lokea rubra. Lochea ini berbentuk serum dan berwarna
\end{abstract}


merah jambu kemudian menjadi kuning. Cairan tidak berdarah lagi pada hari ke-7 sampai hari ke-14 pascapersalinan, kemudian dilanjut lochea alba adalah lochea yang terakhir hari ke-14 Bentuknya seperti cairan putih berbentuk krim serta terdiri atas leukosit dan sel-sel desidua (Saleha, 2009).

Pengawasan masa nifas sangat penting dilakukan untuk menghindarkan adanya kemungkinan-kemungkinan infeksi dan perdarahan post partum. Oleh karena itu penolong atau para bidan hendaknya harus tetap waspada meskipun sudah 24 jam lebih ibu melahirkan karena dikhawatirkan akan terjadi infeksi dan perdarahan post partum sekunder. Sikap demikian juga dapat dapat menyebabkan terganggunnya kerja pembuluh darah dan otot-otot tubuh. Oleh karena itu, kini perawatan ibu nifas lebih aktif dengan dianjurkan untuk melakukan mobilisasi dini (Nakita, 2006).

Mobilisasi dini dapat mempengaruhi pengeluaran lochea karena dapat mencegah terganggunya kerja pembuluh darah dan ligmentum-ligmentum pada waktu involusi uteri. Oleh karena itu perawatan masa nifas sebaiknya lebih aktif dengan dianjurkan mobilisasi dini.

Faktor-faktor

yang

mempengaruhi pengeluaran lochea diantaranya bekuan darah pada serviks, uterus tidak berkontraksi, posisi ibu terlentang, robekan jalan lahir, dan infeksi. Terjadinya perubahan pada pengeluaran lochea dipengaruhi adanya proses involusi uterus (Manuaba,1998).

Jika infeksi terjadi, ibu mengalami gejala demam tinggi dan lochea tidak keluar semestinya disertai bau busuk. Selain itu rahim bisa menjadi lembek dan tidak berkontraksi sehingga bisa terjadi perdarahan. Meski infeksi ini jarang berakibat fatal, tapi bila terjadi komplikasi bisa menyebabkan kematian pada ibu nifas.

Berdasarkan uraian diatas didapatkan permasalahan pengeluaran lochea yang tidak sesuai dengan waktunya hal ini termasuk dalam tanda bahaya masa nifas. Tapi sebenarnya masih banyak ibu nifas yang mengalami masalah bahaya masa nifas, yang tidak diketahui atau terdeteksi oleh tenaga kesehatan. Penyebab tidak diketahuinya bahaya masa nifas yaitu kurangnya pengetahuan ibu nifas. Dimana yang mempengaruhi pengetahuan dari ibu nifas yaitu faktor yang mempengaruhi pengetahuan (pendidikan, usia, pekerjaan, informasi, pengalaman, lingkungan, sosial ekonomi, sosial budaya) dan juga konseling dari tenaga kesehatan selama kehamilan dan setelah persalinan (Notoadmodjo, 2005).

Asuhan masa nifas sangat diperlukan dalam periode ini karena masa nifas merupakan masa kritis untuk mecegah terjadinya suatu masalah tanda bahaya masa nifas. Untuk itu diperlukan suatu peran serta dari masyarakat terutama ibu nifas untuk memiliki pengetahuan tentang tanda-tanda bahaya masa nifas. Selain itu juga diperlukan peran serta dari tenaga kesehatan dengan memberikan konseling selama kehamilan, setelah persalinan, dan melakukan kunjungan rumah yaitu KN.1 dan KN.2 sesuai standart pelayanan. Dari upaya tersebut diharapkan dapat mengetahui dan mengenal secara dini tanda-tanda bahaya masa nifas, 
sehingga bila ada kelainan dan komplikasi dapat segera terdeteksi (Prawirohardjo, 2005).

\section{METODE DAN BAHAN}

Penelitian ini merupakan penelitian Diskriptif . Populasi pada penelitian ini berjumlah 32 responden. Sampel penelitian ini adalah 32 responden. Teknik pengambilan sampel ini adalah menggunakan purposive sampling.

Alat pengumpulan data pada penelitian ini adalah dengan observasi.

\section{HASIL DAN ANALISIS PENELITIAN}

Penelitian ini dilakukan di BPM Asri dan Polindes Permata Bunda Tuban. Pada penelitian ini yang dijadikan responden adalah sebagian ibu nifas yang memenuhi kriteria inklusi.

\section{DATA KHUSUS}

1. Distribusi Data Kriteria Studi Diskriptif tentang Mobilisasi Dini Terhadap Pengeluaran Lochea Pada Ibu Nifas Hari Ke-4 di BPS Asri dan Polindes Permata Bunda Tuban pada bulan Maret-Mei Tahun 2018.

\begin{tabular}{llcc}
\hline No. & $\begin{array}{c}\text { Mobilisasi } \\
\text { Dini }\end{array}$ & $\mathbf{f}$ & $\boldsymbol{\%}$ \\
\hline 1. & Cepat & 21 & 65,6 \\
2. & Lambat & 11 & 34,3 \\
\hline & Jumlah & 32 & 100 \\
\hline
\end{tabular}

Dari tabel diatas 4.1 menunjukan bahwa sebagian besar reposden melakukan mobilisasi dini cepat $21(65,62 \%)$.

2. Distribusi Data Pengeluaran Lochea pada Ibu Nifas di BPS Asri dan

\begin{tabular}{llcc}
\multicolumn{2}{l}{$\begin{array}{l}\text { Polindes Permata } \\
\text { Tuban pada bulan } \\
\text { Mei Tahun 2018 }\end{array}$} & $\begin{array}{c}\text { Bunda } \\
\text { Maret- }\end{array}$ \\
\hline No. & $\begin{array}{l}\text { Pengeluaran } \\
\text { Lochea Hari }\end{array}$ & f & $\%$ \\
& & \\
\hline ke-4 & & \\
\hline 1. & Sesuai & 18 & 56,2 \\
2. & Tidak Sesuai & 14 & 43,7 \\
\hline & Jumlah & 32 & 100 \\
\hline
\end{tabular}

Dari tabel di atas 4.2 menunjukan bahwa sebagian besar responden pengeluaran lochea hari ke-4 sesuai sebanyak $18(56,25 \%)$.

\section{PEMBAHASAN}

Identifikasi Pengeluaran Lochea pada ibu Nifas Hari Ke-4

Berdasarkan tabel 4.2 menunjukkan bahwasebagian besar responden pengeluaran lochea hari ke-4 sesuai.

Lochea adalah ekskresi cairan rahim selama masa nifas. Lochea mengandung darah dan sisa jaringan desidua yang nekrotik dalam uterus. Lochea mempunyai reaksi basa/alkalis yang dapat membuat organisme berkembang lebih cepat dari pada kondisi asam yang ada pada vagina normal. Lochea mempunyai bau yang amis (anyir) meskipun tidak terlalau menyengat dan volumennya berbeda-beda pada setiap wanita. Lochea yang berbau tidak sedap menandakan infeksi. Lochea mengalami perubahan karena proses involusi.

Lochea mempunyai bau yang khas, tidak seperti bau menstruasi. Bau ini lebih terasa tercium pada lochea serosa, bau ini juga akan semakin menyengat apabial bercampur dengan kringat dan harus cermat membedakannya dengan bau busuk yang menandakan adanya infeksi. Lochea dimulai sebagai suatu pelepasan cairan dalam jumlah yang banyak pada jam-jam pertama 
setelah melahirkan. Kemudian lochea ini berkurang jumlahnya sebagai lochea rubra lalu berkurang sedikit menjadi sanguilenta, serosa dan akhirnya lochea alba. Hal yang biasanya ditemui pada seorang wanita adalah adanya jumlah lochea yang sedikit pada saat ia berbaring dan jumlahnya meningkat pada saat ia berdiri. Jumlah rata-rata pengeluaran lochea adalah kira-kira 240-270 ml.

Lochea mengalami perubahan akibat proses involusi, yaitu berawal dari lochea rubra yang keluar selama 2 hari pertama post partum berwarna merah kehitaman, Kemudian menjadi lochea sanguinolenta warnanya merah kuning berisi darah dan lender ini terjadi pada hari ke $3-7$ pasca persalinan, Lochea serosa berwarna kuning dan cairan ini tidak berdarah lagi pada hari ke $7-14$ pasca persalinan, dan dilanjutkan dengan lochea alba cairan putih yang terjadinya pada hari setelah 2 minggu pasca persalinan (Suherni, 2009). Ibu nifas dikatakan pengeluaran lochea normal jika pada hari ke 4 locheanya sudah menjadi lochea sanguinolenta dan tidak normal jika pengeluaran locheanya pada hari ke 4 belum berubah menjadi lochea sanguinolenta.

Dalam penelitian ini masih banyak pengeluaran locheanya tidak normal yaitu sebanyak $14(43,75)$ dari 32 responden. Hal ini kemungkinan selain disebabkan karena kuranganya ibu yang melakukan mobilisasi dini namun juga dapat disebabkan karena gizi, infeksi, kelainan kontraksi uterus, dan juga ASI.

Faktor-faktor

yang

mempengaruhi pengeluaran lochea antara lain yaitu; Pemberian ASI, Moblisasi dini, Gizi, Kelainan
Kontraksi Uterus Saat Persalinan, Infeksi Intra Uteri.

Berdasarkan hasil penelitian dengan observasi antara variabel studi diskriptif tentang mobilisasi dini terhadap pengeluaran lochea.

Mobilisasi dini adalah kebijaksanaan untuk selekasas mungkin membimbing penderita keluar dari tempat tidurnya dan membimbingnya selekas mungkin berjalan. Mobilisasi dini mempunyai keuntungan dalam melancarkan pengeluaran lochea sehingga dapat mengurangi infeksi nifas. Ketika dilakukan mobilisasi dini, maka cairan sekret dari dalam kavum uteri dan vagina akan keluar secara lancar akibat pergerakan ibu nifas. Dilihat dari anatomi alat reproduksi wanita jika ibu tidur terlentang proses pengeluaran lochea bisa terlambat dan jika dilakukan dalam waktu yang lama selama masa nifas maka dapat terjadi adhesi antara labium minora dengan mayora. Adapun faktorfaktor yang mempengaruhi mobilisasi dini adalah Pengetahuan, sosial budaya, Informasi dari petugas kesehatan, Ketidakmampuan atau kelemahan fisik dan mental, Depresi, Nyeri atau rasa tidak nyaman, Kecemasan (Chapman, 2006).

Ketika dilakukan mobilisasi dini maka cairan sekret dalam kavum dan vagina akan keluar secara lancar akibat pergerakan ibu nifas. Jika ibu tidur terlentang proses pengeluaran bisa terlambat, sehingga mobilisasi dini dapat mempengaruhi pengeluaran lochea pada masa nifas oleh karena itu perawatan masa nifas seharusnya lebih aktif untuk dianjurkan pelaksanaan mobilisasi dini masa nifas sesuai dengan tahapanya. 


\section{Kesimpulan}

Berdasarkan hasil penelitian dan pembahasan serta tujuan penelitian dapat

disimpulkan sebagai berikut :

1 sebagian besar ibu nifas di BPS Asri dan Polindes Permata Bunda Tuban melakukan mobilisasi dini dengan cepat.

2 sebagian besar ibu nifas di BPS Asri dan Polindes Permata Bunda Tuban pengeluaran lochea sesuai.

\section{DAFTAR PUSTAKA}

Anggraini Yetti. 2010. Asuhan Kebidanan Masa Nifas.

Carpenito. 2009. DiagnosaKeperawatan Aplikasi pada Praktik Kliniks ed 9. Jakarta : ECG

Chapman, Vicky. 2006. Asuhan Kebidanan Persalinan dan kelahiran. Jakarta : EGC.

Farrel.H. (2001).Perawatanmaternitas. (Hartono.A.,Penerjemah). Jakarta : EGC

Hidayat, A. Aziz Alimul, 2009. Metode Penelitian Kebidanan dan Tehnik Analisa Data. Jakarta, Salemba Medika

Hidayat, A.2007. Riset Keperawatan dan Teknik Penulisan Ilmiah. Jakarta:Salemba medika

Manuaba, IGB, 1998. Ilmu Kebidanan, Penyakit Kandungan dan Keluarga berencana untuk opendidikan Bidan. EGC : Jakarta.

Medscape.com//articler/26/137-

overview.html. Diaskes pada tanggal 15 Mei 2012 jam 18.45.

Muchtar, Rustam. 2003. Sinopsis Obstetri Jilid 1. Jakarta; EGC

Notoatmodjo, soekidjo. (2007).Promosi Kesehatan dan Ilmu Periksa. Jakarta: Rineka Cipta
Notoatmodjo.S.

(2005)

Metodologipenelitiankesehatan.Jak arta :RinekaCipta

Nursalam,

2002.MenejemenKeperawatan.Jaka rta :SalembaMedika

Nursalam (2008).Konsepdan Penerapan Metodologi Penelitian Ilmu Keperawatan:Pedoman Skripsi, TesisdanInstrumentPenelitian Keperawatan.Jakarta :Salemba Medika

Prawirohardjo. 2010. Ilmu Kebidanan. Yayasan bina pustaka sarwono prawirohardjo. Jakarta

Sitti Saleha. 2009. Asuhan Kebidanan Pada Masa Nifas. Jakarta. Salemba Medika.

Sujiyatini. 2010. Catatan Kuliah Asuhan Ibu Nifas. Yogyakarta. Cyrillus Publisher

Syaifudin, 2009.Anatomitubuh mahasiswakeperawatan, Jakarta: SalembaNakita, 2006. Ilmu Keperawatan. http://emedicine. 